\title{
Formation of practical skills modeling and printing of three- dimensional objects in the process of professional training of IT specialists
}

\author{
Ihor Hevko*, Olha Potapchuk, Taras Sitkar, Iryna Lutsyk, and Pavlo Koliasa \\ Ternopil Volodymyr Hnatiuk National Pedagogical University, Department of Computer Technologies, Ternopil, 46027, Ukraine
}

\begin{abstract}
The article discusses the current technology of three-dimensional modeling and prospects for its implementation in the structure of the modern system of professional training of IT specialists according to the concepts of sustainable development. The problems have been actualized and the methodology for three-dimensional modeling and printing has been proposed by using modern software, in particular, the features of using the basic core of geometric design and software preparation of the model for printing have been presented. An algorithm for the formation of practical skills of students in hardware preparation and calibration of 3D printers, the adjustment of the main technological parameters of work, preparation for the manufacture of a spatial model has been proposed. The developed algorithm promotes to the formation of practical skills of modeling and printing three-dimensional objects in future IT-specialists of vocational education, contributes to the formation of their professional competencies. In turn, this contributes to the formation of professional competencies among future IT specialists and creates the need for systematic improvement of knowledge and their creative implementation in practice with a more efficient use of IT technologies, which is the basis in solving the problems of sustainable development of society.
\end{abstract}

\section{Introduction}

\subsection{Formulation of the problem}

Effective and innovative development of the modern information society is impossible without a comprehensive solution to global problems, which solutions are indicated in the ideology of the Sustainable Development Strategy. So, the need arises to ensure a balance of three components: environment-nature, society, and the economy with the priorities of reasonable, sustainable and comprehensive growth [1]. Under such conditions, vocational education and training are the key prerequisites for achieving sustainable development of society, and also a tool to increase the competitiveness and mobility of the country's labor potential [2].

The importance of solving this issue is reflected in the main legislative and regulatory documents of the country. Actual problems of training future specialists in vocational education in the field of computer technology are reflected in the Law of Ukraine "On Higher Education", the National Doctrine of the Development of Education, and industry standards for higher education. The conceptual provisions of vocational education in the context of society's informatization are set forth in the Law of Ukraine "On the National Informatization Program", the Concept of the National Informatization Program, and the State Program "Information and
Communication Technologies in Education and Science", which states that ICT is "an element of the new infrastructure, the main factor in accelerating innovation processes and modernizing the economy" [3].

The peculiarity of the development of the modern information society lies in the phenomenal growth of the possibilities of information and communication technologies (ICT) and their continuous implementation, which has significantly changed the situation in many parts of human activity, including in the field of professional educations. A special place in the educational process of preparing bachelors and masters is given to the study of normative and selective disciplines that provide theoretical knowledge and practical application of three-dimensional modeling software products [8].

Along with a thorough study of the basic command tools and algorithms for constructing individual spatial elements, professional modeling tools and computer design technologies, insufficient attention is paid to modern technologies for the application of such software products. The lack of practical use until recently was caused by a number of reasons, among which, first of all, the lack of material and technical base that would ensure the implementation of the manufacturing technology of designed products in the design process.

With the advent of affordable technical means of production (CNC-machines, 3D-printers), opportunities have grown to better quality training, however, the

* Corresponding author: gevko.i@gmail.com 
intensification of development in this direction has been delayed in default of the absence or imperfection of training algorithms. By the term "educational algorithms" we mean a system of sequences of application of methods and tools that increase the quality of training of future specialists of a certain professional industry, which provides for a comparison of the goal and the actual result of the educational process.

Studying the basics of computer graphics and modeling is becoming one of the most important areas for training specialists in IT technology with a developed set of creative abilities, who are ready for selfdevelopment and self-realization and who are fluent in 3D modeling skills.

\subsection{Research analysis}

Famous scientists in the field of information technology, in particular, V. Bykov, M. Zhaldak, M. Leshchenko identified the main characteristic features of the content of computer literacy and revealed the methodological aspects of teaching information modeling $[3,7]$. The domestic and foreign research thoroughly covered the problem of application of modern technologies of geometric modeling in the learning process [5-8]. The problems of the applied application of three-dimensional modeling and printing technologies are also disclosed $[4,9]$. An analysis of the scientific and pedagogical literature indicates that the problem of the practical training of specialists remains one of the most actual.

An analysis of theory and practice indicates that the level of practical skills of young specialists is insufficient and does not meet international standards and the requirements of the modern labor market, which negatively affects the quality of their professional training [10]. Therefore, we believe that the features of studying three-dimensional modeling and printing in the process of practical training of future specialists in vocational education should be disclosed in more detail. This is due to a number of contradictions: the need for consistent, targeted involvement of future specialists in professional practical experience in the conditions of informatization and the lack of educational technologies for the formation of their professional culture; the increasing role of project activities in the professionalization and socialization of young professionals and the low level and fragmented nature of its formation in the learning process using traditional technologies; requirements of employers to the level of information and communication competencies of graduates, but not the sufficiency of appropriate scientific and methodological support.

In our opinion, an integrated approach to the formation of the necessary level of their practical training and information culture as a whole will significantly improve the quality of training of future specialists in vocational education in the field of IT technology.

The research purpose: to disclose the algorithm of three-dimensional modeling and printing of spatial objects to form the practical skills of future specialists in vocational education in the field of IT technology.

Object of study: formation of practical skills of future IT specialists using the tools of modeling technology and printing of three-dimensional objects.

\section{Research methodologies}

To conduct the study, an analysis of the requirements for specialists in the field of computer technology in the modern labor market (work.ua, jobs.aol.com, rabota.ua, etc.) was made. The competencies provided by educational programs, which a qualified specialist should possess, are also analyzed. Based on a comparison of educational goals and requirements for specialists in the labor market, the most relevant areas for improving the process of forming practical skills of future specialists in vocational education in the field of computer technology were identified.

In this regard, an analysis of three-dimensional modeling technologies was carried out, which are the most common and in demand at the present stage of development of information technologies. The study involved the application of methods for analyzing the requirements for specialists in the field of computer technology and the knowledge of this problem, a comparative analysis of software products of threedimensional graphics, a generalization of the results.

\section{Research results}

In modern conditions of modernization of education, students of higher educational institutions (HEI) need to learn an increasing amount of educational material in order to become competitive specialists in the field of their professional activity. It is a question not only of a quantitative accumulation of knowledge, but also of a qualitative restructuring of the entire system of educational activity of the HEI. The constant replenishment of not only knowledge, but also professional skills, throughout life becomes now necessary for any specialist. Particular attention in the educational process is acquired not by transferring certain knowledge to students, but by developing future specialists' needs for their constant replenishment, the formation and consolidation of practical professional skills [11].

Therefore, it can be argued that the main objective of the HEI is the professional training of competitive specialists with professional skills and the ability to work creatively and proactively. In turn, vocational training is the acquisition of qualifications in the relevant specialty, which in the future, based on the general fundamental foundations of the educational process, supplements them with specific specialized competencies, reflecting the characteristics of a particular field of activity [12].

In order to form a high-quality practical training of specialists in vocational education, we consider it necessary to take into account the features of the process 
of modeling and printing three-dimensional objects using the example of building an architectural object. This is due to the specifics of the professional skills of future specialists in vocational education in the field of computer technology - their diversity and interdisciplinarity.

Consider the process of designing three-dimensional objects by means of computer-aided design (CAD), which includes the following stages: analysis, the formation of technical specifications, topological description, the synthesis of array alternative structures, geometric modeling, analysis of results, optimization, generation and transmission of information for manufacturing on a 3D printer [13].

Considering the production technology and taking into account the type of the simulated object (in this case, the engineering one), the stage of geometric modeling always occupies a special place in the structure of the general design technology, due to its complexity and considerable complexity. The creation of a threedimensional model of the future product is implemented by a wide variety of 3D-modeling programs, among which the SolidWorks environment occupies a special place.

SolidWorks [13] has sufficient command tools for creating spatial objects of varying complexity. Particular attention should be paid to the study of the sketching environment by students, the features of working with linear and curvilinear graphics, editing tools (curves, chamfers, scaling, mirror reflections), determining the
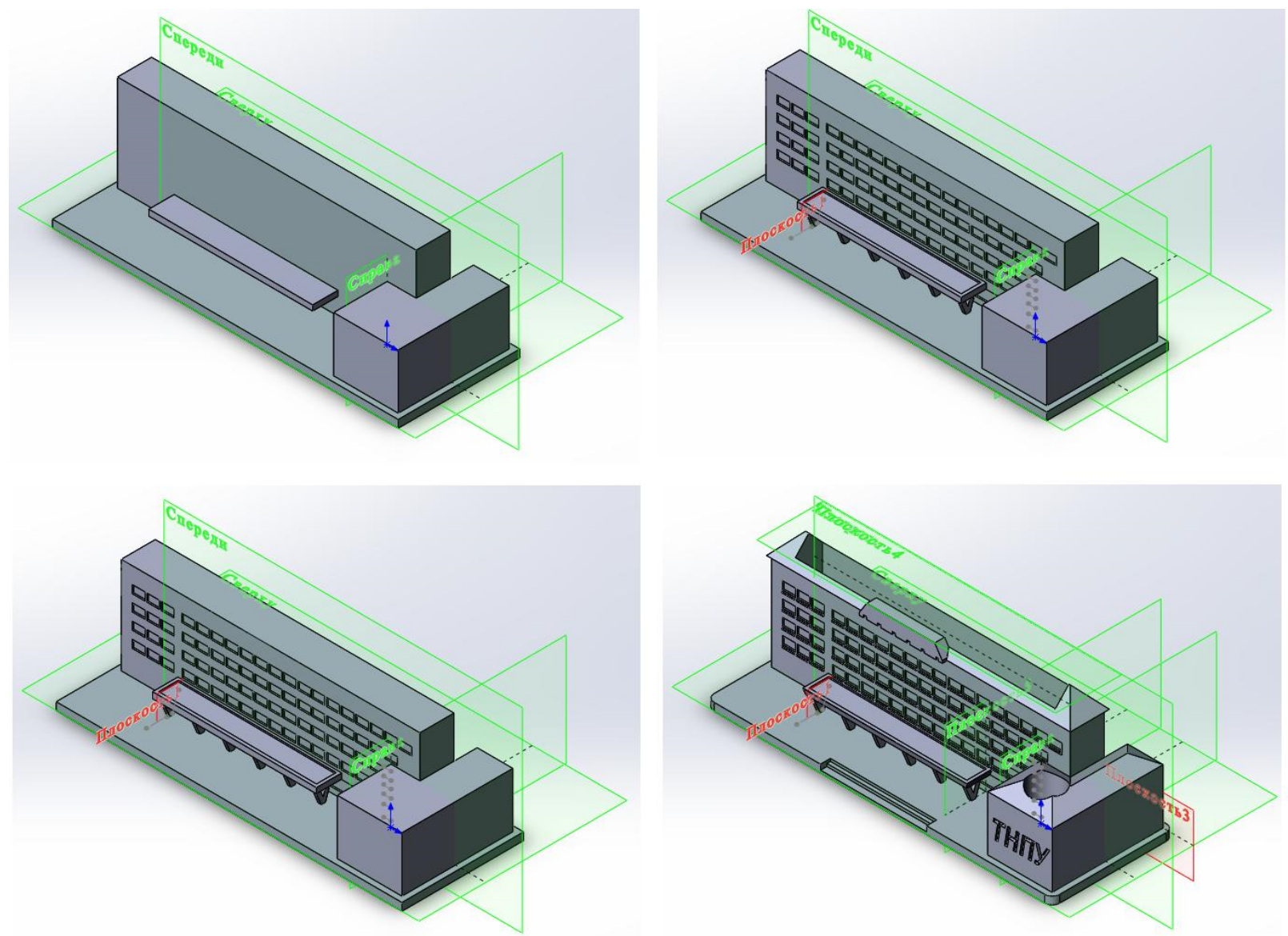

geometry of sketch objects (dimensions, geometric constraints). This greatly expands the applied practical skills of students and reduces the complexity of their activities.

The study of three-dimensional graphics is based on the basic methods of forming spatial elements and provides a detailed analysis of the features and functionality of each of them through a detailed study of instruction managers (sliding windows, panels, additional modes, etc.). Particular attention must be paid to the model building algorithms using the build manager, the ability to correctly evaluate geometry, which can often be complex and determine the method of creating the foundation and the sequence of further modeling and editing of the future product.

In general, generalized 3D modeling technology involves the step-by-step creation of individual elements, starting with sketches, creating a spatial base model based on them, forming and editing spatial elements and categories (fig. 1). In this case, the model includes a relief inscription of the university abbreviation, which has been presented in Cyrillic (fig. 2).

The three-dimensional model created in this way can be used by modern systems and CNC (computer numerical control) processing technologies using the SolidCAM modular environment [14], with which you can develop the manufacturing technology of a product modeled in SolidWorks, from metal or wood.

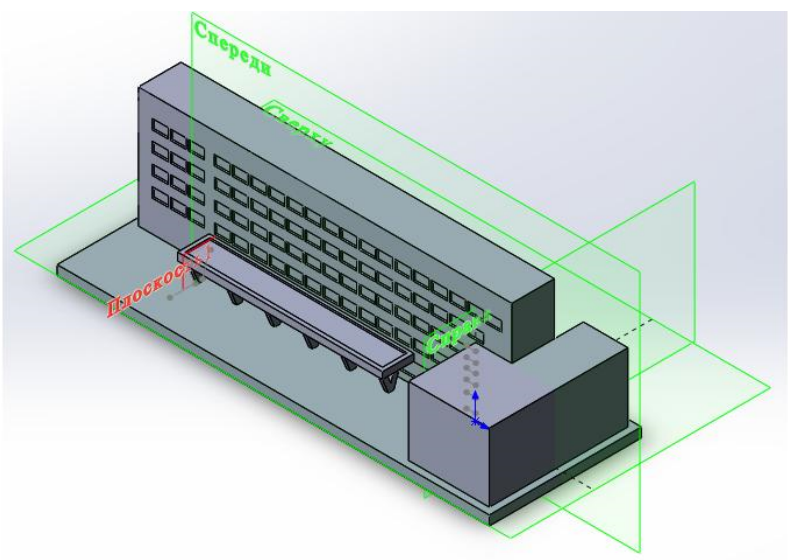

Fig. 1. The stages of creating a spatial model of the product. 


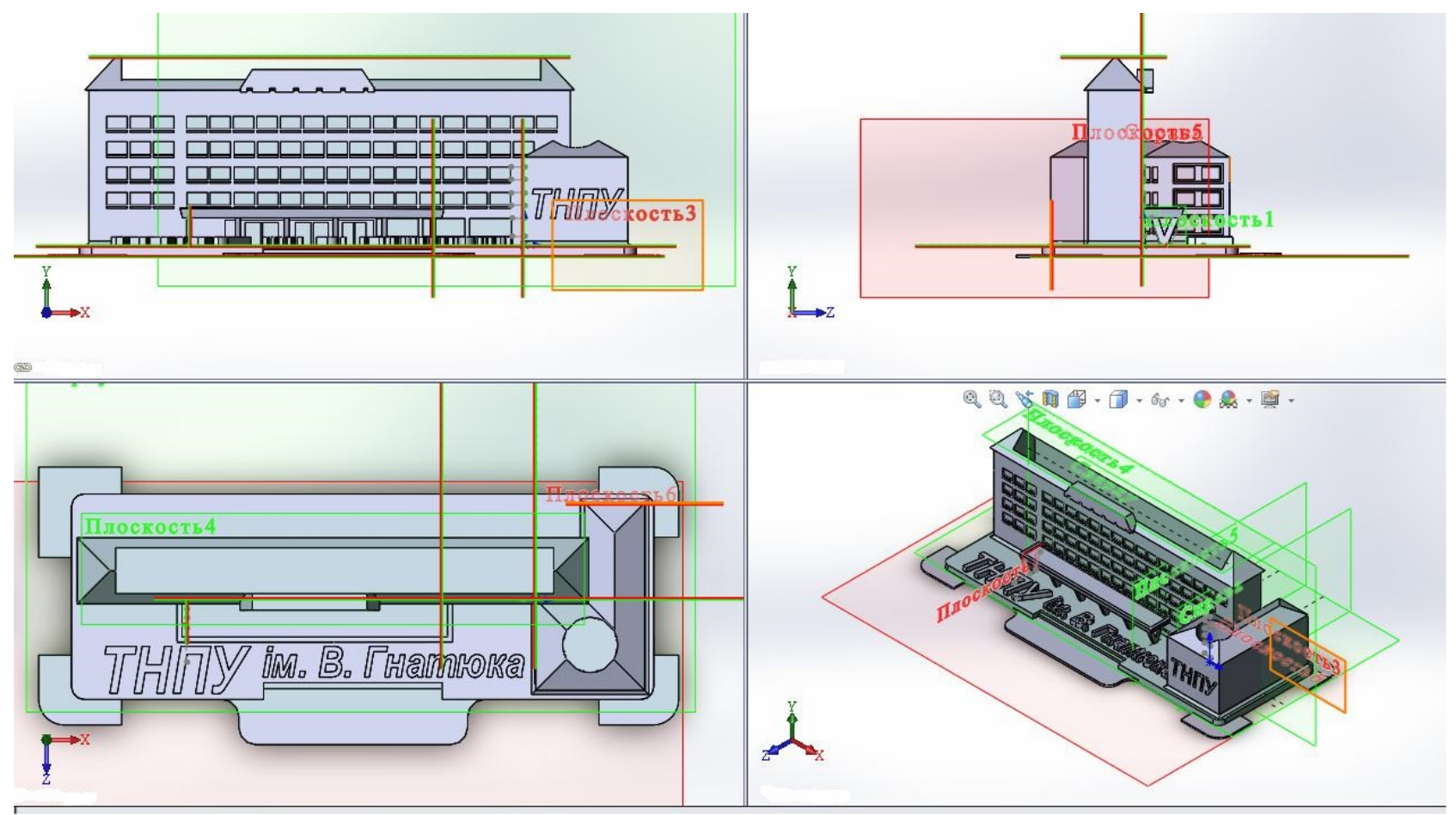

Fig. 2. The completed view of the spatial model of the product.

In this case, according to the task, we consider the features of manufacturing a model of plastic mass. The manufacture of these types of products is quite successfully implemented by the technologies of software and hardware 3D printing, using plastic masses (ABS, PLA, nylon, etc.) as a material.

Today, there is a wide variety of $3 \mathrm{D}$ printing computer programs, among which are Kissslicer, Cura, Slic3r, CraftWare, 3DTin, Repetier-Host. 3D printing software includes computer programs for interaction with hardware device, drivers for the 3D printer, and also may include configuration files. It should be noted that the mentioned software products are quite common, some of them have advanced functionality and relative complexity. In order to select the appropriate software, it is necessary to analyze the software, that was mentioned above, in accordance with standard ISO 9126: 2001 by such parameters: functionality, usability, efficiency, program interface [15].

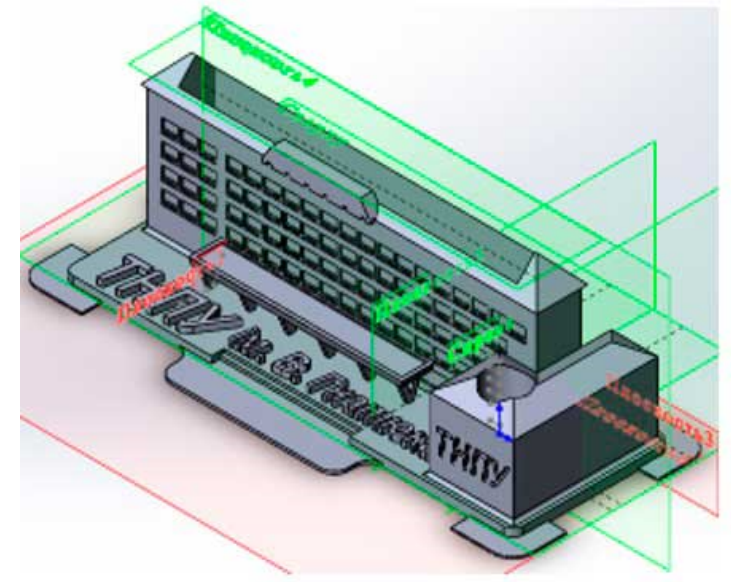

A comparative analysis of the mentioned software found that a significant advantage according to the criteria of convenience and an intuitive interface at the stage of learning 3D printing technologies is the Cura software environment, in which, in addition to standard tools (setting print quality, material parameters), the functions of calculating the mass of the finished product, printing time and the like are implemented also [16]. However, the Cura software environment, like other 3D printing support products, does not provide support for file formatting. The main input data format is the STL format, in which information is stored as an array of triangular data describing the surface and their normals.

Thus, the geometric model that is created in any 3D modeling software product must be broadcast in the STL format (Fig. 3). It should be noted that due to the intensive development of $3 \mathrm{D}$ printing, most CAD systems, including SolidWorks, support this function.

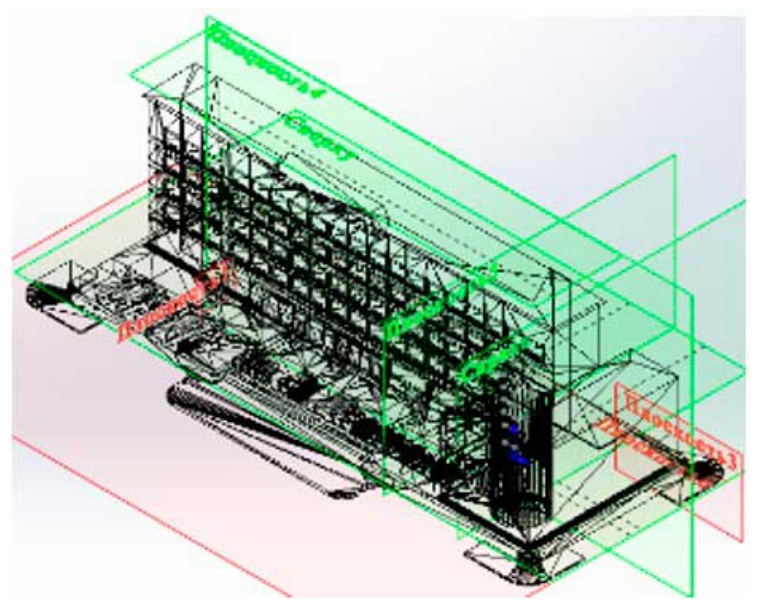

Fig. 3. Comparative model views in * .sldprt format (SolidWorks format) and * .stl 


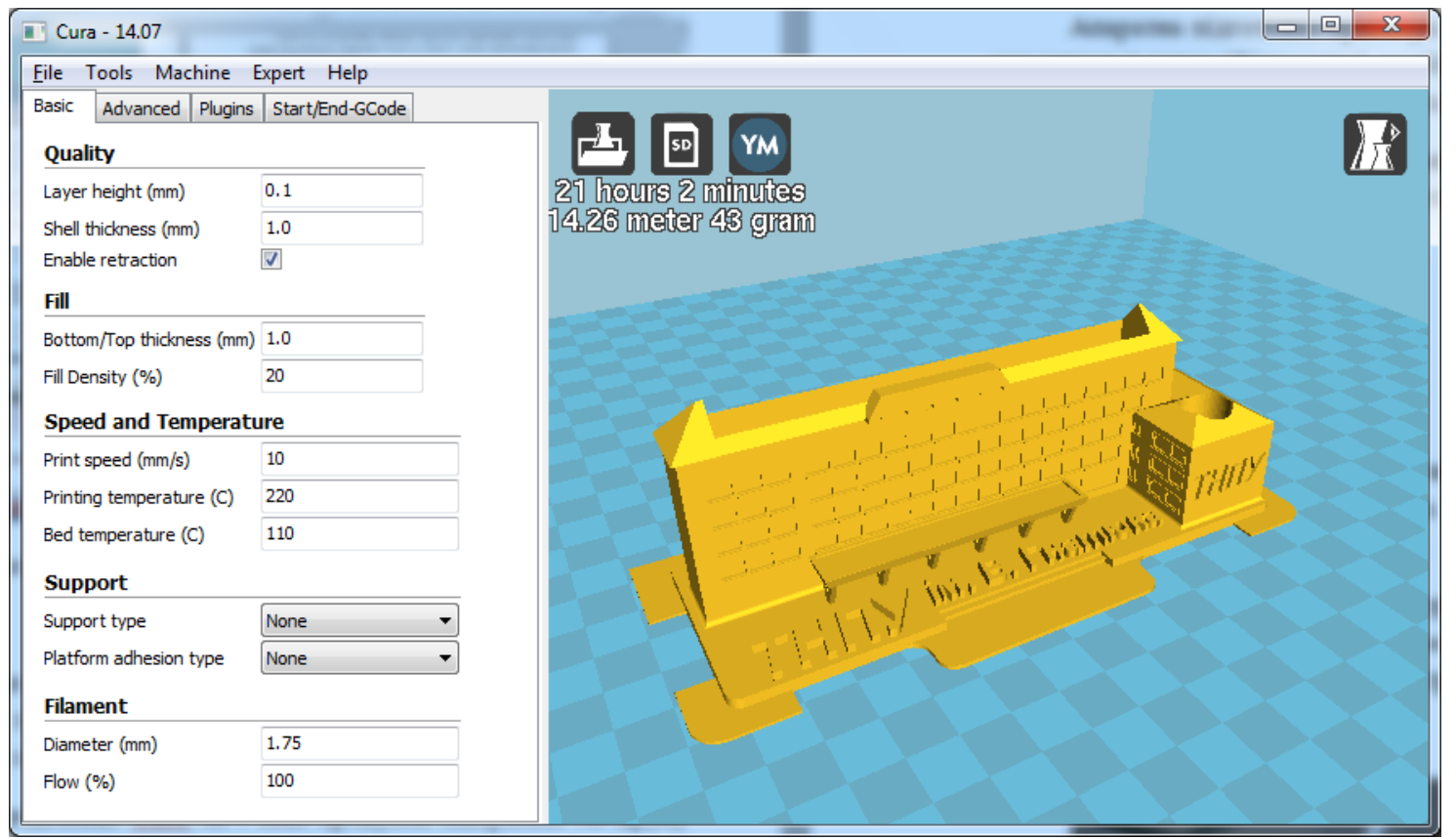

Fig. 4. The Cura software interface and downloaded model in * .stl format.

The technological parameters of printing is the Cura software environment are configured on the Basic, Advanced, Plugins, Start and End G-codes tabs (Fig. 4). The basic settings are located on the Basic tab: print quality, filling, print speed and temperature, print support options for the model and plastic thread.

When setting the print quality parameters, the determining indicators are Layer height $(\mathrm{mm})$, which should not exceed $1 / 2$ the nozzle diameter of a 3D printer. For a filament thickness of $1.75 \mathrm{~mm}$ and a nozzle diameter of $0.4 \mathrm{~mm}$, the maximum value of the layer thickness can be considered $0.2 \mathrm{~mm}$. In order to obtain objects of improved quality, the layer thickness is recommended to be taken in the range of $0.1-0.15 \mathrm{~mm}$, however, it is necessary to take into account the increase in the total printing time of the model.

Shell thickness $(\mathrm{mm})$ - determines the wall thickness of the model when printing thin-walled objects or objects with a reduced fill factor. The practical value of the wall thickness is selected based on the specific geometric parameters of the object, but it is recommended to take it within 1-2 mm. A wall thickness value of less than $1 \mathrm{~mm}$ is considered insufficient to ensure minimum model rigidity requirements, however, for small-sized models (10-30 mm), this thickness can be considered optimal.

The thickness of the upper and lower walls is controlled by a separate indicator Bottom /Top thickness (mm), which in the absence of special design requirements can be equated to the thickness of the shell. However, it is not recommended to accept this value less than $0.6 \mathrm{~mm}$.

Economic indicators of plastic consumption and model stiffness are implemented by the Fill Density (\%) indicator. By default, for most cases, the fill factor is $20 \%$. However, if it is necessary to obtain rigid models, and also taking into account the design features of the model, the fill factor can be $100 \%$. This significantly increases the consumption of material and printing. In the case of applying a fill factor of less than $10 \%$, a significant decrease in structural rigidity and imperfections in printing can be observed.

Setting speed and temperature conditions provides high-quality and technological parameters of printing. The most determining parameter is the Print Speed ( $\mathrm{mm}$ ), which determines the speed at which the nozzle moves and model builds. For printing models with overall geometric dimensions of $100-120 \mathrm{~mm}$ and the presence of small elements, it is recommended to set the speed parameter $10-15 \mathrm{~mm} / \mathrm{s}$. It is not recommended to set a speed of more than $25 \mathrm{~mm} / \mathrm{s}$ due to a significant decrease in print quality, the appearance of vibrational forces on the supporting structure of the printer and the rapid wear of the drive elements.

The printing temperature (Printing temperature $(C)$ ) and the table temperature (Bed temperature $(C)$ ) of the printer must be coordinated with the type of plastic used. Support technology provides for the printing of additional (not provided by geometry) model elements, due to the impossibility of the formation of plastic mass in the air. Such support is implemented both for individual elements of the model (Support type) and its foundation (Platform adhesion type).

The settings of the plastic thread (filaments) are implemented by the obligatory condition of the numerical value of the diameter (Diameter $(\mathrm{mm})$ ) of the used filaments and the fill factor (Flow (\%)). For modern technology of 3D printing, the use of filaments with a diameter of 1.75 or $3.0 \mathrm{~mm}$ is provided. When setting the fill factor, it must be taken into account that the maximum value can cause irregularities and, accordingly, nozzle strokes during printing, because the minimum value will cause the fragility of the printed model.

The Cura environment is actually a slider program, designed to convert the surface of a geometric array into 
a sequence of slices by parallel planes with subsequent translation of the data into a G-code

G-code - the general name of a programming language, which is regulated by the relevant standard and is intended for programming equipment with numerical control. The model G-code file is the source information file for the hardware of the 3D printer and can be downloaded using the direct interface or using an SD card [17].

To visualize the process of layer-by-layer printing, the G-code of the model can be loaded directly into the Cura environment (Fig. 5). Using the slider tool located in the graphics area provides a layered display of the sequence of future printing of the model.

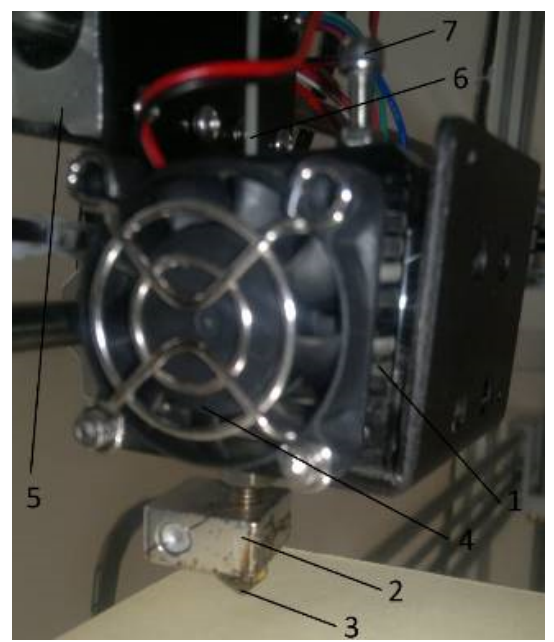

Fig. 5. General view of the print head of a 3D printer: 1 - gear module for filing the thread (inside the structure), 2 - heating element; 3 - nozzle; 4 - cooling fan; 5 - case with guides; 6 plastic thread (filament) 7 - support screw.

The hardware preparation of a 3D printer should include the following steps: preparation of plastic filament (filaments), printer calibration, desktop preparation, downloading a model file, printing a model.

The first step in preparing the printer for hardware is installing filaments in the print head of the printer. Structurally, it is made in the form of a toothed filament feed module, a heating element, a nozzle, a cooling fan, and a housing with guides (Fig. 5).

The printer calibration technology provides for the formation of technological gaps between the working surface of the table and the nozzle in order to ensure high-quality layering of the plastic mass. The correct insertion of the plastic mass ensures its normal distribution, the correct adhesion of the initial and subsequent layers, while ensuring high-quality manufacture of the product. The necessary clearance is ensured by adjusting the screws of the desktop at four points along the perimeter. A prerequisite for this is the preheating of the printing table to operating temperature.

The preparation of filaments involves the release of the technological opening of the filament by pressing the support screw, threading the end of the filament into the feed opening of the print head, followed by capture by the gear module and filing the filament to the heating element.
The preparation of the desktop, in addition to calibrating the gaps, also includes the need to lubricate it with an adhesive to ensure the necessary adhesion of the first layer to the work surface, which is especially important when printing ABS models with plastic. In this case, glue on a PVP basis can be recommended. It should also be noted that for PLA plastic such a problem is not observed.

Downloading the model can be implemented using direct interface technology and using external memory modules (microSD). Printing a model is the final step that must be carried out only when all previous steps are completed. The downloaded file G-code of model, in addition to geometric information, contains data on the manufacturing process. So, after starting the model for printing, the extruder nozzle and the printer table are preheated. Information about the operation is displayed on the printer information panel (Fig. 6).

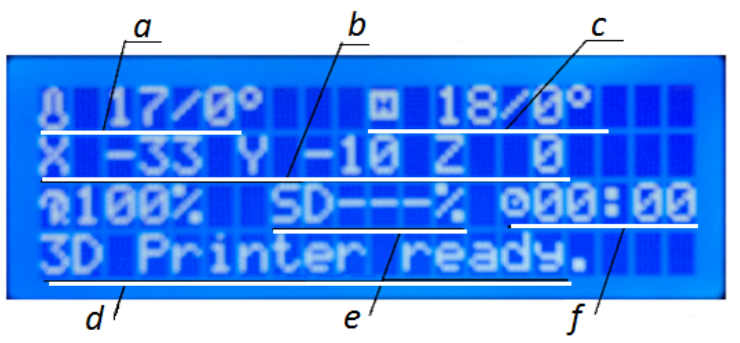

Fig. 6. Printer Modes Dashboard: a - nozzle temperature control; $\mathrm{b}$ - extruder position coordinates; $\mathrm{c}$ - table temperature control; $\mathrm{d}$ - printer ready status; $\mathrm{e}$ - the percentage of task execution; $\mathrm{f}-$ the total time of the task.

In the case of the preparation of technological operating modes, the $3 \mathrm{D}$ printer starts working. As a result, we get a finished product that fully corresponds to the created three-dimensional model in SolidWorks environment (Fig. 7).
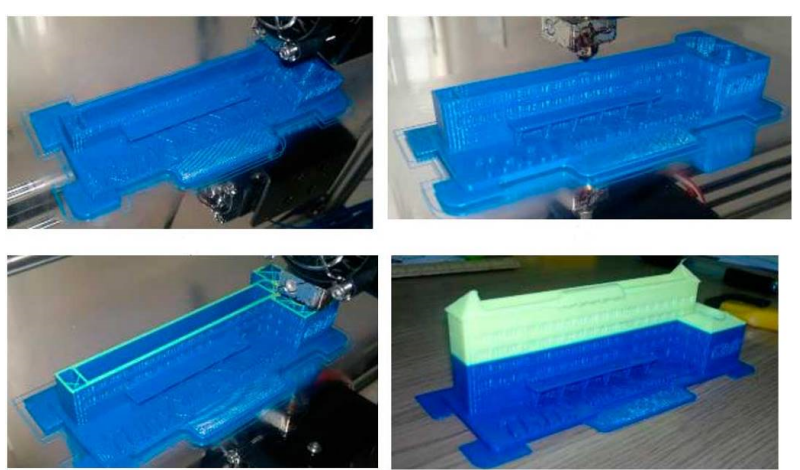

Fig. 7. Technological stages of printing a solid-state model.

Thus, the algorithm of three-dimensional modeling and printing can be divided into the following stages: modeling of the object, preparation of the data format and loading of the model, configuring software for printing the model, configuring hardware for the 3D printer, printing the model. Students' implementation of each stage of the algorithm involves the formation of certain skills and the acquisition of practical skills (Table 1).

To test the readiness of future IT specialists to implement the study of $3 \mathrm{D}$ printing technologies in the 
educational process, experimental studies have been conducted with a group of students and the results of the input and final control have been analyzed. Carrying out such a study makes it possible to find out the level of students' practical skills of applying 3D modeling and printing technologies in the context of introducing modern IT technologies into the practical activities of future professional education specialists, according to the concept of sustainable development.

Table 1. Stages of the training algorithm.

\begin{tabular}{|c|l|l|}
\hline $\begin{array}{c}\text { Name of } \\
\text { the stage }\end{array}$ & $\begin{array}{c}\text { Basic theoretical know- } \\
\text { ledge and skills }\end{array}$ & $\begin{array}{l}\text { Acquired practical } \\
\text { skills }\end{array}$ \\
\hline $\begin{array}{c}\text { Modeling } \\
\text { of object }\end{array}$ & $\begin{array}{l}\text { Knowledge of the sequence } \\
\text { and tools for work in a a } \\
\text { sketch environment, the abi- } \\
\text { lity to use commands to cre- } \\
\text { ate 3D elements and catego- } \\
\text { ries }\end{array}$ & $\begin{array}{l}\text { Creation of computer } \\
\text { 3D models of objects } \\
\text { ty degrees. }\end{array}$ \\
\hline $\begin{array}{l}\text { Preparing a a } \\
\text { data format } \\
\text { for printing }\end{array}$ & $\begin{array}{l}\text { Knowledge of basic graphic } \\
\text { data formats, knowledge of } \\
\text { data export procedure }\end{array}$ & $\begin{array}{l}\text { Formation of the ini- } \\
\text { tial data of 3D mo- } \\
\text { dels and preparation } \\
\text { for printing }\end{array}$ \\
\hline $\begin{array}{l}\text { Hardware } \\
\text { settings of } \\
\text { 3D printer }\end{array}$ & $\begin{array}{l}\text { Knowledge of the interface, } \\
\text { structure and principle of } \\
\text { operation of the main struc- } \\
\text { tural elements of a 3D prin- } \\
\text { ter }\end{array}$ & $\begin{array}{l}\text { Calibration of 3D } \\
\text { printer desktop and } \\
\text { preparation of fila- } \\
\text { ment }\end{array}$ \\
\hline $\begin{array}{c}\text { Printing } \\
\text { the model }\end{array}$ & $\begin{array}{l}\text { Knowledge of coordinate } \\
\text { configuring technology }\end{array}$ & $\begin{array}{l}\text { Printing of products } \\
\text { with strict observan- } \\
\text { ce of geometric di- } \\
\text { mensions and quality } \\
\text { of surface }\end{array}$ \\
\hline
\end{tabular}

Analysis of the research results allowed us to establish that after conducting such classes, students significantly increased academic performance in academic disciplines, which include the study of computer modeling and three-dimensional visualization (Table 2), which indicates an increase of the level of formation of practical skills of students (EG experimental group, $\mathrm{N}$ - the total number of students, $\mu_{1}-$ the average score of students in the group, $n-$ the number of students at level, IC - is the input control, FC - the final control).

Table 2. Dynamics of student performance.

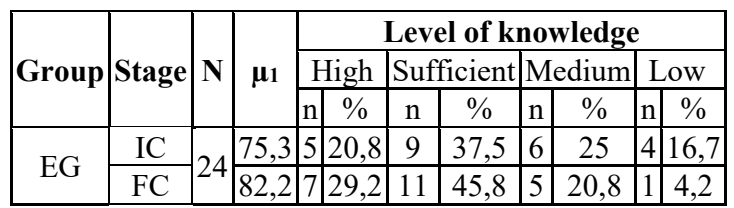

Accordingly, the quality of students' knowledge increased by $26.7 \%$, and the average score increased: $\Delta \mu \mathrm{E}=6.9$ (Fig. 8).

We believe that for the qualitative formation of practical skills of students in modeling and printing three-dimensional objects, it is necessary to introduce the study of such technologies as an essential component of their educational process. This contributes to the formation of professional competencies among future IT specialists and creates the need for systematic improvement of knowledge and their creative implementation in practice with more efficient use of IT technologies, which is the basis for solving problems of sustainable development of society.

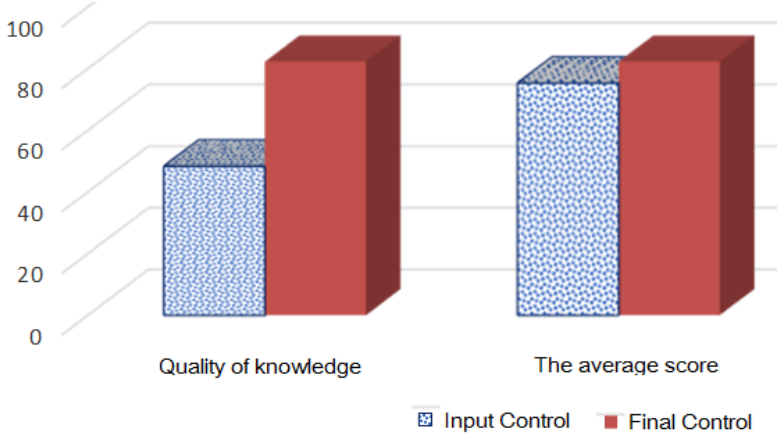

Fig. 8. The analysis of the experimental results.

\section{Conclusions and future prospects}

The key requirement for the training of IT professionals for the sustainable development of society is the formation of practical skills in using modern technologies, which allows them to develop their professional competence and increase their mobility and competitiveness in the labor market.

The organization of practical training and assimilation by students of a sufficient amount of knowledge defined by the curriculum programs, the formation of professional skills and competencies acquired by students in practical classes in the process of theoretical training, will further facilitate the easy inclusion of future specialists of IT technology in their professional activity.

Application of the developed learning algorithm contributes to the formation of practical skills of modeling and printing three-dimensional objects in future IT professionals. Thus, this contributes to the formation of professional competencies, makes it possible to foster steady interest in future professional activities, creates the need to systematically update their knowledge and apply them creatively in practice.

The presented algorithm can be successfully used also for technological purposes for the manufacture of three-dimensional objects for various purposes. The main advantage of using this technology for the manufacture of three-dimensional objects is the availability and low cost of manufactured models.

Prospects for further research are the development of methodological support for the formation of competence of modeling and 3D printing of spatial objects of complex geometric structure in future professional education specialists.

\section{References}

1. EC, Europe 2020 - a European Strategy for Smart, Sustainable and Inclusive Growth (European Commission, Brussels, 2010(

2. V.O. Radkevych, Profesiyna osvita i navchannya dlya staloho rozvytku suspil'stva (Vocational 
education and training for the sustainable development of society). Profesiyno-tekhnichna osvita 4(69), 7-11

3. V. Bykov, Teoretyko-metodolohichni zasady informatyzatsiyi osvity ta praktychna realizatsiya informatsiyno-komunikatsiynykh tekhnolohiy $v$ osvitniy sferi Ukrayiny (Theoretical and methodological foundations of informatization of education and the practical implementation of information and communication technologies in the educational sector of Ukraine). (Comprint, Kyiv, 2019)

4. K. Osadcha, H. Chemerys, Dobir zasobiv tryvymirnoho modelyuvannya dlya formuvannya hrafichnoyi kompetentnosti maybutnikh bakalavriv komp'yuternykh nauk (Selection of 3D modeling tools for forming the graphic competency of future bachelors of computer science). Information Technologies and Learning Tools 62(6), 70-85 (2017)

5. I. Hevko, O. Potapchuk, I. Lutsyk, V. Yavorska, V. Tkachuk, Methods building and printing 3D models historical architectural objects. SHS Web Conf. 75, 04016 (2020). doi:10.1051/shsconf/20207504016

6. I. Hevko, Pidvyshchennya yakosti pidhotovky maybutnikh fakhivtsiv profesiynoyi osvity $\mathrm{v}$ haluzi komp"yuternykh tekhnolohiy zasobamy 3-D modelyuvannya, (Improving the quality of training of future specialists in computer technology by means of 3-D modeling), Visnyk NPU “Chenihivs'kyy kolehium” 158(2), 203-211 (2019)

7. M. Zhaldak, Komp"yuterno-oriyentovani zasoby navchannya matematyky, fizyky, informatyky (Computer-aided teaching of mathematics, physics, computer science). (Dinit, Kyiv, 2004)

8. H. Budinoff, S. McMains, Relationships between Spatial Visualization Ability and Student Outcomes in a 3D Modeling Course. Paper presented at the Abstracts of the ASEE EDGD 72nd Mid Year Conference, Jamaica, January 4 (2018)

9. R. Noorani, 3D printing: technology, applications, and selection (CRC Press, 2017)

10. Yu. Byelova, Proektna diyal'nist' maybutn'oho inzhenera-pedahoha (Project activity of future engineer-teacher). Naukovyy chasopys NPU im. M. Drahomanova 51(5), 17-21 (2015)

11. O. Varganova, Praktychna pidhotovka yak konkurentna perevaha vypusknykiv VNZ na rynku prats (Practical training as a competitive advantage of university graduates in the labor market). Vyshcha osvita Ukrayiny 4, 84-89 (2005)

12. P. Luzan, Modul'no-kompetentnisnyy pidkhid $u$ pidhotovtsi kvalifikovanykh robitnykiv budivel'noyi ta mashynobudivel'noyi haluzey (IPTO, Kyiv, 2015)

13. L. Fedik, Osoblyvosti systemy avtomatyzovanoho proektuvannya SolidWorks (Features of SolidWorks computer aided design). Komp"yuterno-intehrovani tekhnolohiyi: osvita, nauka, vyrobn. 15, 127-130 (2014)
14. O. Leshenko, Pidvyshchennya efektyvnosti tekhnolohichnoyi pidhotovky vyrobnytstva cherez zastosuvannya $\mathrm{CAD} / \mathrm{CAM} / \mathrm{CNC}$ system (Improving the efficiency of technological preparation of production through the use of CAD / CAM / CNC systems). Visnyk Pryazovs'koho derzhavnoho tekhnichnoho universytetu 36, 148-156 (2018)

15. Ye.V. Vavilov, Seriya standartiv SQuaRE yak osnova zabezpechennya vymoh do yakosti ta otsinky prohramnykh zasobiv (SQuaRE Standards Series as a Basis for Quality Assurance and Software Evaluation). Zbirnyk naukovykh prats' Odes'koyi derzhavnoyi akademiyi 1, 129-139 (2015)

16. V.Yu. Mitin, Obzor oborudovaniya, programmnogo obespecheniya, vozmozhnostey i etapov trekhmernoy pechati (Overview of hardware, software, features and stages of three-dimensional printing). Vestnik Permskogo Universiteta 41(2), 67-74 (2018)

17. S. Kim, Transforming algorithm of 3D model data into G-code for 3D printers in Distributed Systems, in Advances in Computer Science and Ubiquitous Computing. UCAWSN 2016, CUTE 2016, CSA 2016, ed. by J. Park, Y. Pan, G. Yi, V. Loia. Lecture Notes in Electrical Engineering, vol. 421 (Springer, Singapore, 2016), pp. 1074-1078 